\title{
Pigment chromatic adaptation in Cyclotella caspia Grunow (Bacillariophyta)
}

\author{
Donato Seiji ABE \& Sônia Maria Flores GIANESELLA-GALVĀO
}

Instituto Oceanográfico da Universidade de São Paulo

(Caixa Postal 9075, 01065-970 São Paulo, SP, Brasil)

- Abstract: The diatom Cyclotella caspia Grunow, isolated from surface waters of the Ubatuba region (São Paulo State, Brazil) was submitted to different light spectral distributions for examination of its adaptative response. Growth rate and the photosynthetic pigments chlorophyll $a$, chlorophyll $c$, carotenoids and phaeopigments were measured under white, blue and red light of the same intensity ( 8 and $20 \mu \mathrm{E} \cdot \mathrm{cm}^{-2} \cdot \mathrm{s}^{-1}$ ). Growth rate increased under blue light while red light increased chl $a$ concentration. The relative proportion of $\operatorname{chl} a$ and carotenoids did not change, demonstrating the absence of complementary chromatic adaptation.

- Descriptors: Phytoplankton, Photosynthetic pigments, Chromatic adaptation, Light effects, Growth, Chlorophylls, Carotenoids, Cyclotella caspia.

- Descritores: Fitoplâncton, Pigmentos fotossintéticos, Adaptaçōes cromáticas, Efeitos da luz, Crescimento, Clorofilas, Carotenoides, Cyclotella caspia.

\section{Introduction}

Photoadaptative responses of phytoplankton pigments have often been studied and are rather well known with respect to light intensity effects (Prézelin 1976, 1981; Perry et al., 1981; Harding et al., 1983; Richardson et al., 1983).

In marine environments, light quality differs both with depth and location. In estuarine environments, with high turbidity, light attenuates rapidly with depth and the predominant subaquatic light varies from green to red; in oceanic waters, with a small amount of particulate and dissolved material, blue-green light predominates (Jerlov, 1976).

Diatoms are an important and ubiquitous group and their accessory pigments absorb radiation over a broad range of visible wavelenghs (Jeffrey, 1980). The purpose of this study was to determine if the diatom Cyclotella caspia Grunow responds to differences in spectral distributions of ambient light with pigment changes, and whether such changes occur as complementary chromatic adaptation.

Meeson \& Faust (1985) emphasize that most studies have not made a clear distinction between the responses due to spectral quality and those due to total irradiance. To separate these responses, 1) comparisons must be

Contr. no. 727 do Inst. oceanogr. da Usp. made in different color spectra but at similar total irradiances and 2) irradiance must be expressed in quanta.

These responses were first separated by Jeffrey \& Vesk (1977) and Vesk \& Jeffrey (1977), working with the diatom Stephanopyxis turris (Grev.). Using total energy rather than quantum flux density, they showed that cells grown in blue green light at low irradiance $\left(400 \mathrm{~W} \mathrm{~cm}^{-2}\right)$ had higher pigment content than cells grown in white light at the same irradiance. Faust et al. (1982), working with the dinoflagellate Prorocentrum minimum (Pavillard) Schiller under four different light qualities, showed that cells grown in blue light at low photon flux density (PFD) (11.5 $\mu$ mol quanta $\left.\mathrm{m}^{-2} \mathrm{~s}^{-1}\right)$, grew faster and had lower pigment content than cells grown in red, green or white light at similar PFD.

Complementary chromatic adaptation has often been observed in cyanobacteria (Bogorad, 1975; Kohl \& Nicklisch, 1981; Glover et al., 1987; Prézelin et al., 1989). Cyanobacteria show no change in pigment ratios in response to total irradiance, so that change in the pigment ratio may indicates a response to light quality change. However, in diatoms, dinoflagellates and chrysophytes, pigment ratios change in response to total irradiance, and any change in accessory pigments causes a change in chl $a$ (Richardson et al., 1983). To detect complementary chromatic adaptation in these groups, it is necessary to 
examine the magnitude of the pigment response at similar quantum flux densities (Meeson \& Faust, 1985).

\section{Materials and methods}

\section{PFD normalization}

Light sources with three spectra were used: white, blue and red. For each spectrum, two fluorescent lamps of $40 \mathrm{~W}$ were assembled in a horizontal incubator: Osram daylight lamps provided white light, Sylvania F40T12/AZ provided blue light and Sylvania F40t12/VE provided red light. The emission spectra of the colored lamps, furnished by the manufacturer, are shown in Figs 1,2 and 3. Celluloid colored filters, with spectral transmittance obtained with a Zeiss PMQ-3 spectrophotometer were used over the corresponding lamps to narrow the spectrum and to reduce the irradiance coming from the mercury bands inherent in fluorescent lamps (Fig. 4).

Experimental flasks were maintained above the lamps to permit illumination from the bottom. Flasks were covered with opaque shields to exclude light from other sources.

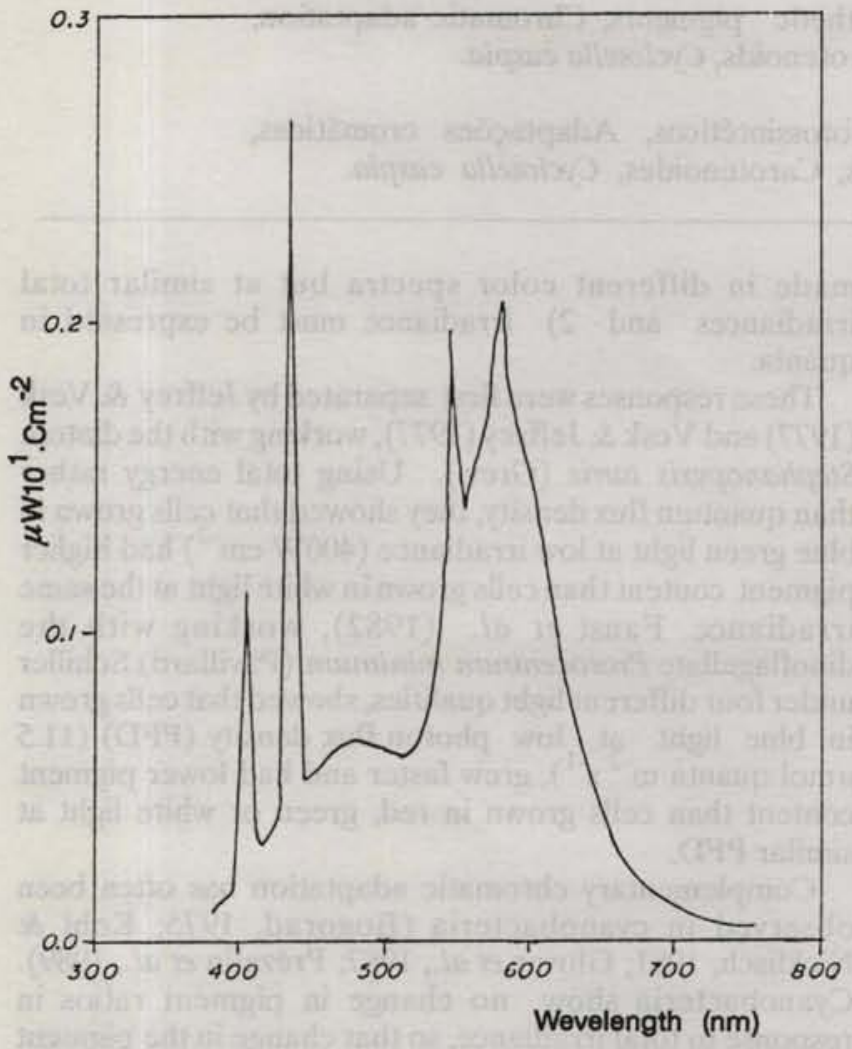

Fig.1. Emission spectra of the Osram daylight lamp (furnished by manufacturer).
Two PFDs were used in the experiments $\left(8 \mu \mathrm{E} \cdot \mathrm{m}^{-2} \cdot \mathrm{s}^{-1}\right.$ and $20 \mu \mathrm{E} \cdot \mathrm{m}^{-2} \cdot \mathrm{s}^{-1}$ ), measured by a LI-COR Inc. (Lambda LI-185) quantameter, both below the level of photoinhibition of chlorophyll synthesis. Irradiance normalization of the different light sources was obtained by neutral filters.

\section{Culture conditions}

Cultures of the diatom Cyclotella caspia were isolated from coastal waters off Ubatuba-SP by Dr. E. Aidar. During the experiments the algae were maintained in $f / 2$ medium (Guillard \& Ryther, 1962) under continuous illumination and at $21^{\circ} \mathrm{C}$ temperature.

First, the culture was transfered to $250 \mathrm{ml}$ Erlenmeyer flasks with $150 \mathrm{ml}$ of $\mathrm{f} / 2$ medium. Subsamples were maintained under each different light quality during 36 hours to allow photoadaptation. After this time, experimental flasks were inoculated in triplicate with $1.5 \times 10^{4}$ cells $\mathrm{ml}^{-1}$.

In a first stage, cells were grown to determine growth rate and $\mathrm{dN} / \mathrm{dt}$ max under each light quality. This point is necessary to be established to ensure a low concentration of degraded pigments at the next stage of the experiment, when pigments were analysed.

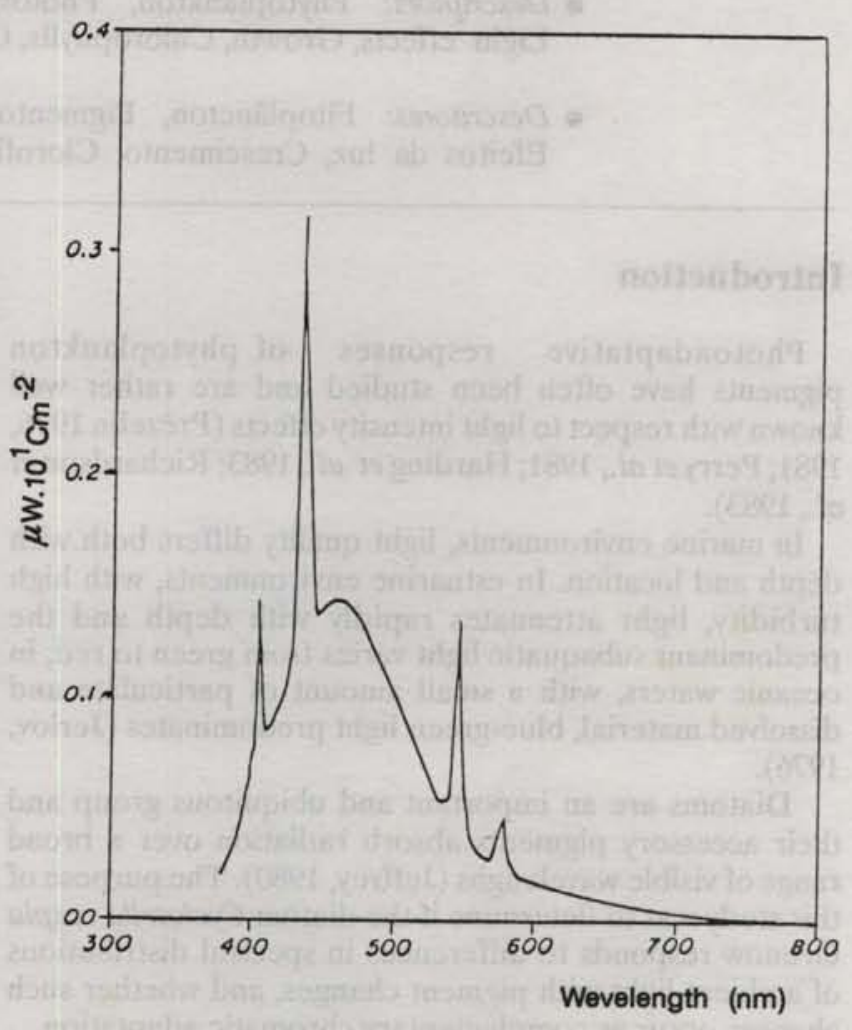

Fig. 2. Emission spectra of the Sylvania F40T12/AZ (blue) lamp (furnished by manufacturer). 


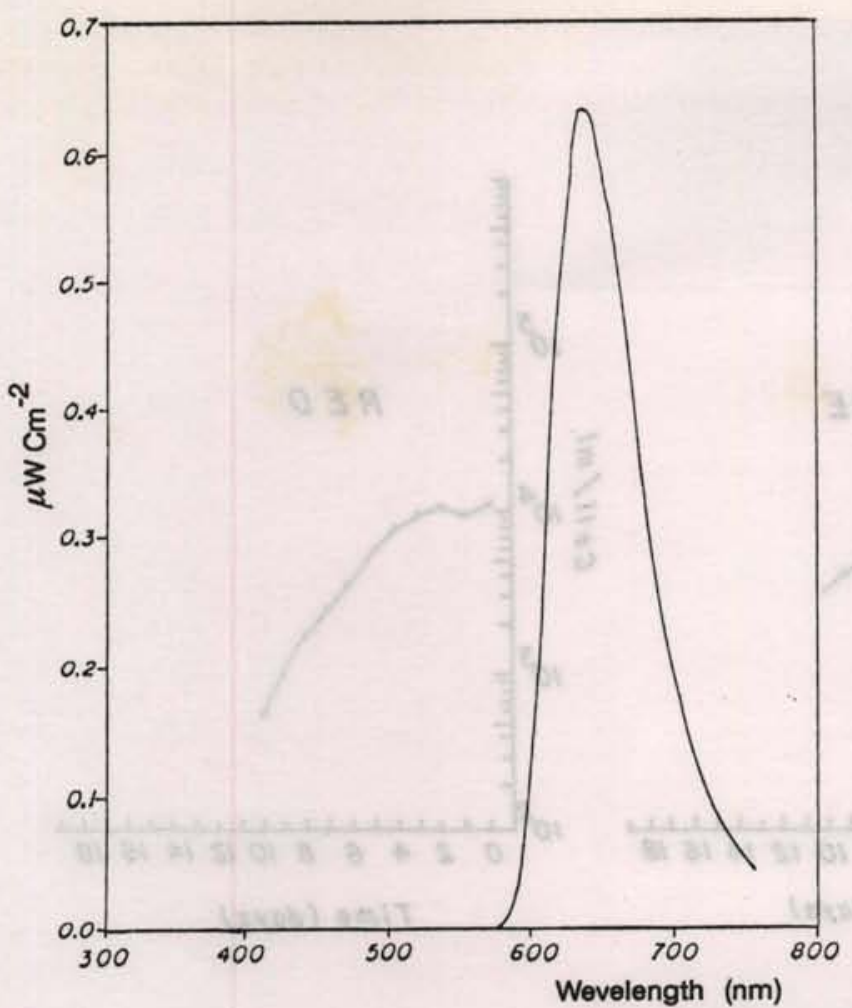

Fig. 3. Emission spectra of the Sylvania F40T12NE (red) lamp (furnished by manufacturer).

Subsamples were obtained every 24 hours for growth rate determination. Cell counts were made with Nageotte hemacytometer chambers at cell densities lower than $10^{4}$ cells $\mathrm{ml}^{-1}$, Agasse-Lafont chambers were used for densities between $10^{4}$ and $10^{5}$ cells.ml ${ }^{-1}$ and Fuchs-Rosenthal for cell densities higher than $10^{5}$ cells.ml ${ }^{-1}$.dN/dt max was attained after 3 days for cells illuminated with blue light, after 5 days for red light and 6 days for white light.

\section{Pigment analysis}

Pigments were analysed by the time of $\mathrm{dN} / \mathrm{dt} \max$ for each light spectrum, to assure a similar physiological state for the cultures. Extraction was in $90 \%$ acetone, and concentrations were determined for $\mathrm{chl} a$ and $\mathrm{c}_{1}$ (Jeffrey \& Humphrey, 1975), carotenoids (Parsons et al., 1984) and phaeopigments (Lorenzen, 1967) using a Zeiss model PMQ-3 spectrophotometer. Pigments were expressed in pg $10^{-1}$ cell $^{-1}$.

\section{Statistical analyses}

Growth rates and pigment concentrations were submitted to single factor analysis of variance (ANOVA) to test the null hypothesis $\mathrm{H}_{0}: \mu 1=\mu 2=\mu 3$ ( $\left.\mathrm{Zar}, 1984\right)$. Tukey multiple comparison test was applied (Zar, op. cit.) when $\mathrm{H}_{0}$ was rejected.

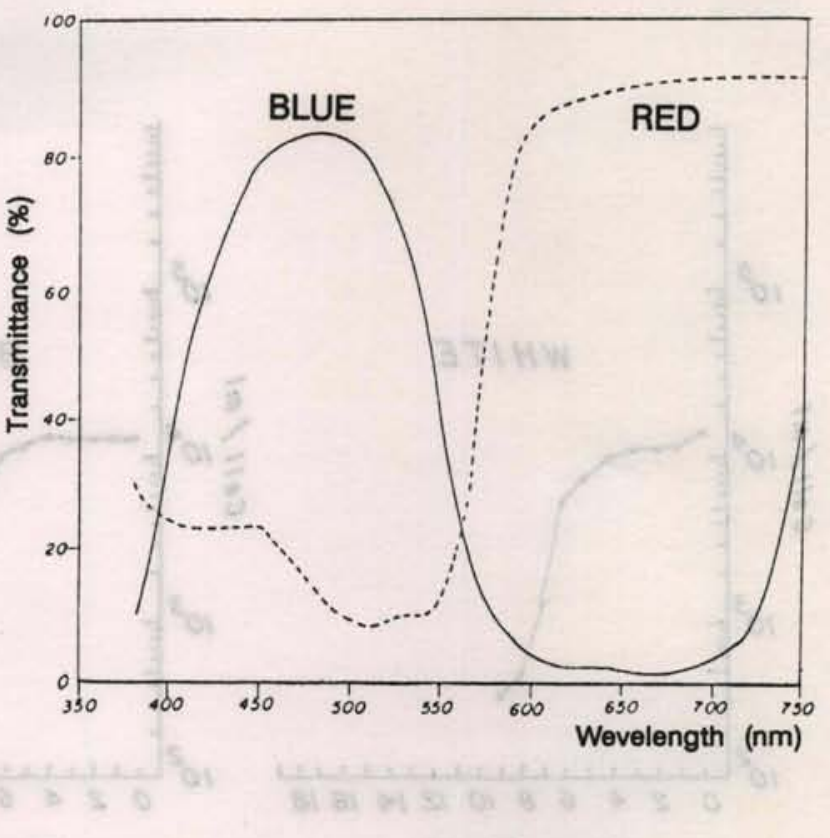

Fig.4. Transmission spectra of the celluloid filters used in the experiment.

\section{Results}

\section{Growth rate}

Cultures submitted to the different light spectra at $8 \mu \mathrm{E}$. $\mathrm{m}^{-2} . \mathrm{s}^{-1}$ PFD did not grow (Fig. 5), showing that this light level was below the compensation irradiance for this population. At $20 \mu \mathrm{E} \cdot \mathrm{m}^{-2} \cdot \mathrm{s}^{-1} \mathrm{PFD}$, cells in blue light grew better than cells grown in the other bands at the same PFD (Fig.6). The treatment with blue light showed, by ANOVA and Tukey test, significantly higher growth rates than those with red or white lights (Table 1).

\section{Photosynthetic pigments}

Analysis of variance of cell number showed that cultures submitted to the three spectral qualities presented similar cell numbers by time of sampling for pigments analysis (Table 2).

Different pigment concentrations per cell are presented in Table 3. Chl $a$ concentration was lowest in cells grown in blue light and highest in cells grown in red light. The treatment with white light showed an intermediate result, not statistically different from the others.

ANOVA of chl $c$, carotenoids, phaeopigments, chl $a$ : carotenoid, $\operatorname{chl} a: \operatorname{chl} c$ and carotenoids:chl $c$ ratio for the different treatments showed no significant differences at $\alpha=5 \%$ (Table 4). 

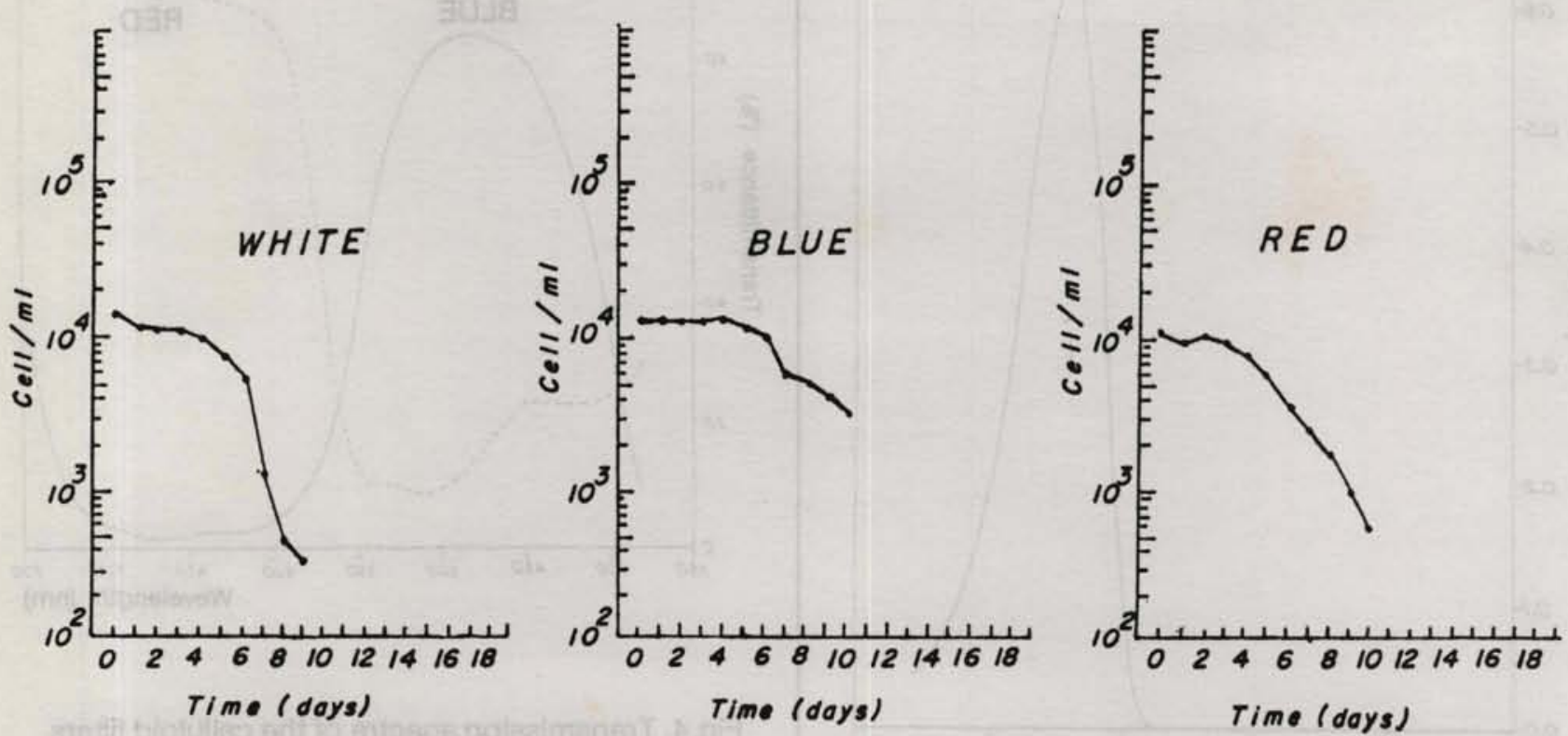

Fig.5. Growth curves for Cyclotella caspia growing in Guillard f/2 medium under $8 \mu \mathrm{E} \cdot \mathrm{m}^{-2} \cdot \mathrm{s}^{-1}$ PFD.
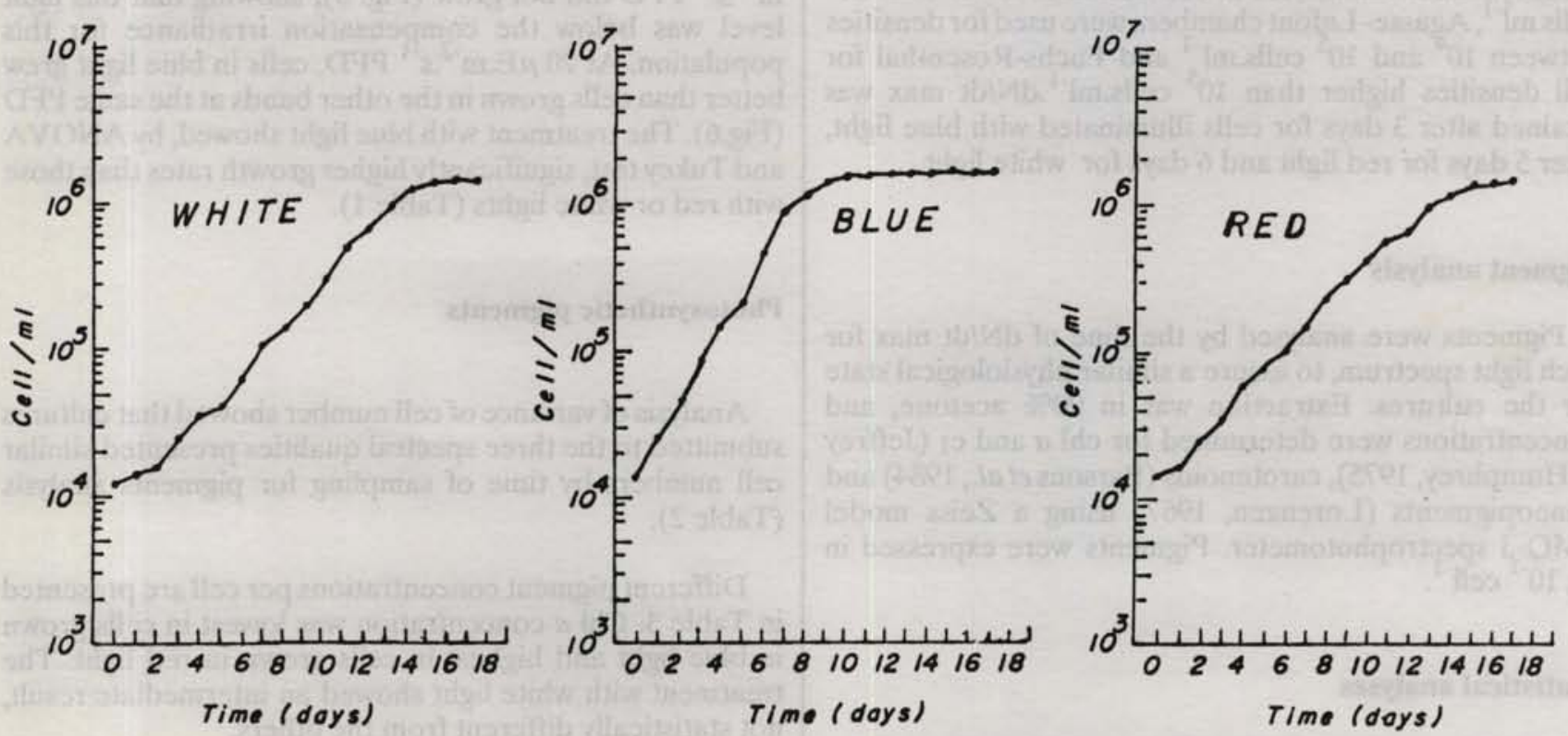

Fig. 6. Growth curves for Cyclotella caspia growing in Guillard $\mathrm{t} / 2$ medium under $20 \mu \mathrm{E} \cdot \mathrm{m}^{-2} \cdot \mathrm{s}^{-1} \mathrm{PFD}$. 
Table 1. ANOVA and Tukey multiple comparison test for growth rate (div./day) in Cyclotella caspia under the three light quality, $20 \mu \mathrm{E} \cdot \mathrm{m}^{-2} \cdot \mathrm{s}^{-1}$ PFD

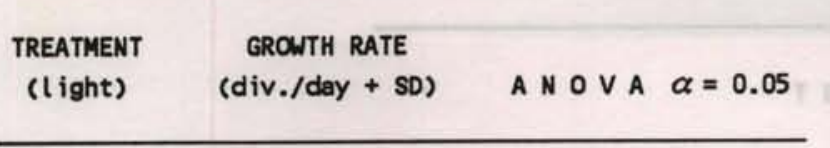

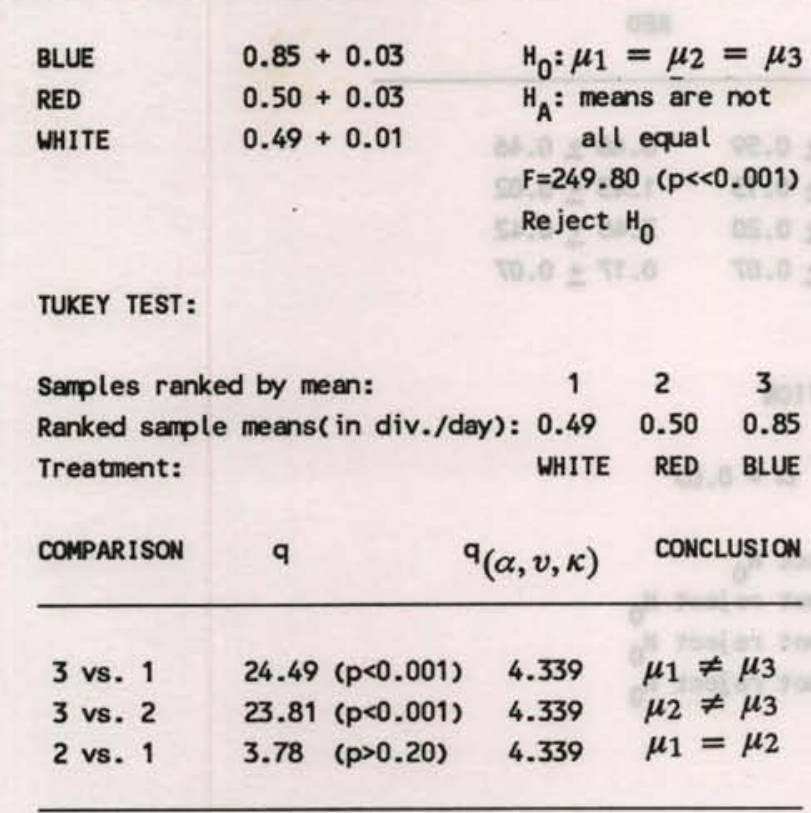

$$
\begin{aligned}
\text { SD } & =\text { standard deviation; } \\
q & =q \text { value of Tukey test } ; \\
\alpha & =\text { significance level }=0.05 ; \\
v & =\text { error degree of freedom }=6 ; \\
\kappa & =\text { total number of means being tested }=3
\end{aligned}
$$

Table 2. ANOVA for log of cell number per $\mathrm{ml}$ by time of sampling for pigments analysis in Cyclotella caspia under the three light quality, $20 \mu \mathrm{E} \cdot \mathrm{m}^{-2} \cdot \mathrm{s}^{-1}$ PFD

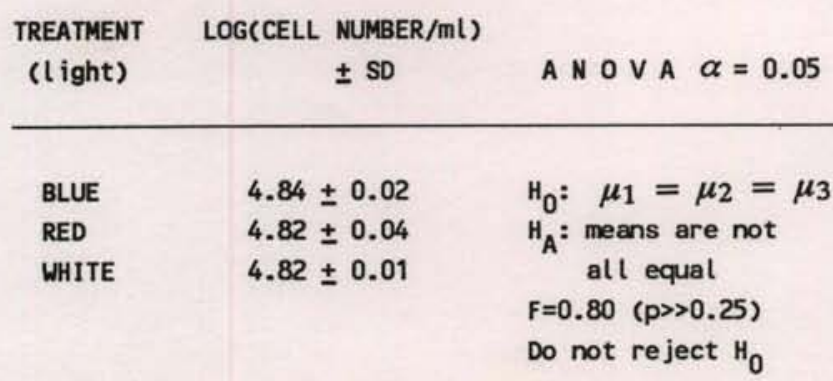

SD $=$ standard deviation;

$\alpha=$ significance level

\section{Discussion}

\section{Growth rate}

C. caspia showed results similar to those observed in $P$. minimum by Meeson \& Faust (1985): both grew faster under blue light at low PFD and had lower pigment content than cells grown in red or white at similar PFD.

Wallen \& Geen (1971a,b), who studied the effect of blue, green and white light on the growth and photosynthetic rate of Dunaliella tertiolecta (Butcher) and Cyclotella nana (Hustedt), also observed high values of growth and photosynthetic rate when these algae were illuminated with blue light at $37 \mu \mathrm{E} \cdot \mathrm{m}^{-2} \cdot \mathrm{s}^{-1}$ intensity. They also verified that blue and green light changed the direction of algal metabolism in favor of protein synthesis, whereas the white light caused carbohydrate synthesis. These results confirm the hypothesis that blue light causes the conversion of photosynthetic products in new cells, because algae that grow in this spectral quality have a higher cellular division rate than those grown in other spectral qualities.

\section{Photosynthetic pigments}

Meeson \& Faust (1985) verified a clear increase in the peridinin:chl $c$ ratio in $P$. minimum illuminated with blue light but only at low irradiances. They concluded that complementary chromatic adaptation is a function of PFD, because this phenomenon was not verified at higher light intensities.

The studies of Jeffrey \& Vesk (1977), Vesk \& Jeffrey (1977), Shimura \& Fujita (1975) and the present work support the statement of Halldal (1974) that complementary chromatic adaptation probably does not occur in phytoplankton groups that use chl $c$ and carotenoids as accessory pigment.

The present data shows that spectral differences at the same PFD stimulate adaptative effects in C. caspia as if it had been submitted to PFD variations: a simultaneous increase or decrease of all pigment concentrations occurs, in response to light quality variation. This response suggests a change at photosynthetic unit (PSU) density and not on the density of light-harvesting pigments per photosystem.

Vesk \& Jeffrey (1977) observed an increase in thilakoids concentration in cells of the diatom $S$. turris illuminated by different light qualities. This response could be explained by the incapacity of the algae to change pigment ratio in the PSUs and solely changing the absorption capacity of the pigments. Carotenoids absorb primarily blue light as does the Soret band of chl $a$ and predominate only in JerlovI (Jerlov, 1976) underwater environments. To absorb the same number of quanta under red light, the cells could possibly increase their light harvesting chl $a$, diverting their metabolic path from cell division. Higher efficiency of cellular division occurs under blue light with low pigment production, as verified by Meeson \& Faust (op. cit.) with P. minimum.

The present study shows that the diatom $C$. caspia presents chromatic adaptation responses at low photon flux densities $\left(20 \mu \mathrm{E} \cdot \mathrm{m}^{-2} \cdot \mathrm{s}^{-1}\right)$, with lower values of chl $a$ in blue light when compared with white or red light. 


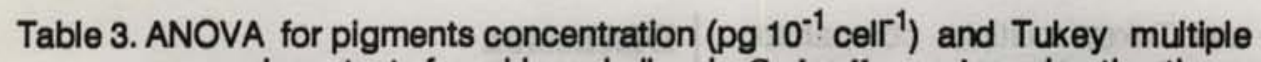
comparison test for chlorophyll a in Cyclotella caspia under the three light quality, $20 \mu \mathrm{E} \cdot \mathrm{m}^{-2} \cdot \mathrm{s}^{-1} \mathrm{PFD}$.

\section{TREATMEN T}

PIGMENT

\begin{tabular}{llll} 
(pg. $10^{-1}$ cell $^{-1}$ ) & WHITE & BLUE & RED \\
\hline Chlorophyll a \pm SD & $7.51 \pm 0.36$ & $6.82 \pm 0.59$ & $8.48 \pm 0.46$ \\
Chlorophyll c \pm SD & $1.47 \pm 0.12$ & $1.28 \pm 0.13$ & $1.43 \pm 0.02$ \\
Carotenoids \pm SD & $2.99 \pm 0.14$ & $2.72 \pm 0.20$ & $3.40 \pm 0.42$ \\
Phaeopignents \pm SD & $0.31 \pm 0.19$ & $0.10 \pm 0.07$ & $0.17 \pm 0.07$
\end{tabular}

A N O V A FOR PIGMENTS CONCENTRATION

$H_{0}: \mu_{1}=\mu_{2}=\mu_{3}$

$\mathrm{H}_{\mathrm{A}}$ : means are not equal $\quad \alpha=0.05$

PIGMENT

Chlorophyll a $\quad F=7.10 \quad(p<0.05) \quad$ Re ject $\mathrm{H}_{0}$

Chlorophylt C $F=1.40(p>0.25) \quad$ Do not re ject $H_{0}$

Carotenoids $\quad F=4.67(p>0.05) \quad$ Do not re ject $H_{0}$

Phaeopignents $F=1.87(p>0.20) \quad$ Do not re ject $H_{0}$

TUKEY TEST FOR CHLOROPHYLL a

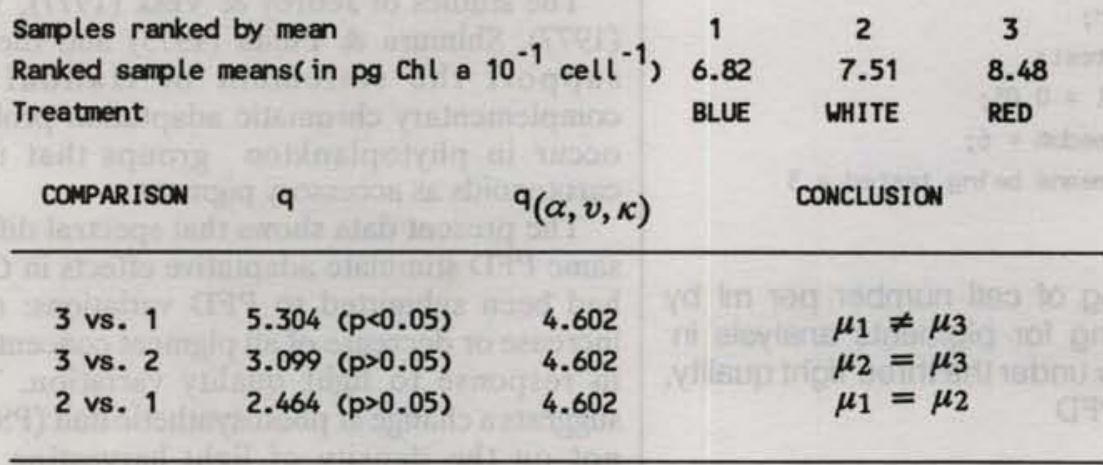

SD = standard deviation;

$q=q$ value of Tukey test;

$\alpha=$ significance level $=0.05$;

$v=$ error degree of freedom $=6$;

$\kappa=$ total number of means being tested $=3$ 
Table 4. ANOVA for $\mathrm{Chl} a$ : Carotenoids ratio in Cyclotella caspia under the three light quality of $20 \mu \mathrm{E} \mathrm{m}-{ }^{2} \cdot \mathrm{s}^{-1}$ PFD

\begin{tabular}{lcl}
$\begin{array}{c}\text { TREATMENT } \\
\text { (light) }\end{array}$ & $\begin{array}{c}\text { Chl a:Caroten.RATIO } \\
\pm \text { SD }\end{array}$ & A N O V A $\alpha=0.05$ \\
\hline BLUE & $2.52 \pm 0.02$ & $H_{0}: \mu_{1}=\mu_{2}=\mu_{3}$ \\
RED & $2.51 \pm 0.20$ & $H_{A}=$ means are not \\
WHITE & $2.51 \pm 0.17$ & all equal \\
& & F=0.007 (p>0.25) \\
& & Do not re ject $H_{0}$
\end{tabular}

SD = standard deviation;

$\alpha=$ significance level

However, this adaptation does not correspond to complementary chromatic adaptation (Engelmann, 1983), because the relative proportion between the pigments remained constant in each treatment.

Future investigations shold focus on the metabolic products under different light spectra that should permit different ecological strategies of the species in the environment.

\section{Resumo}

A diatomácea Cyclotella caspia Grunow, isolada de águas superficiais da regiāo de Ubatuba (Estado de São Paulo, Brasil), foi submetida a diferentes intervalos espectrais de luz com a finalidade de se examinar sua resposta adaptativa. Foram medidos a taxa de crescimento e os pigmentos fotossintéticos clorofila $a$, clorofila $c$, carotenóides e feopigmentos, sob luz branca, azul e vermelha de mesmas intensidades ( 8 e $\left.20 \mu \mathrm{E} \cdot \mathrm{cm}^{-2} \cdot \mathrm{s}^{-1}\right)$. A taxa de crescimento aumentou sob luz azul, sendo que a concentração de clorofila $a$ aumentar sob luz vermelha. A proporção relativa de cl $a$ e carotenóides nāo variou, demonstrando a ausência de adapatação cromática complementar.

\section{Acknowledgements}

We wish to thank Dr. G. R. Hasle for the species identification, Dr. E. Aidar for the facilities at the Algae Culture Lab, and Dr. R. Owen and two anonymous reviewers for comments on earlier drafts.

\section{References}

BOGORAD, L. 1975. Phycobiliproteins and complementary chromatic adaptation. Ann Rev Plant Physiol, 26:369-401.

ENGELMANN, T. W. 1883. Farbe und Assimilation. Bot. Ztg., 41:1-29.

FAUST, M. A.; SAGER, J. C. \& MEESON, B. W. 1982. Response of Prorocentrum mariae-lebouriae (Dinophyceae) to light of different spectral qualities and irradiances: growth and pigmentation. J. Phycol., 18:349-356.

GLOVER, H. E.; KELLER, M. D. \& SPINRAD, R. W. 1987. The effects of light quality and intensity on photosynthesis and growth of marine eukaryotic and prokaryotic phytoplankton clones. J. expl mar. Biol. Ecol., 105:137-159.

GUILLARD, R. R. L. \& RYTHER, J. D. 1962. Studies of marine plankton diatoms. I. Ciclotella nana Husted and Detonula confervacea (Cleve). Gran. Can. J. Microbiol., 8:229-239.

HALLDAL, P. 1974. Light and photosynthesis of different marine algal groups. In: Jerlov, N. G. \& Steeman Nielsen, E., eds Optical aspects of oceanography. London, Academic Press. p. 345-360.

HARDING JR., L. W.; MEESON, B.W.\& TYLER, M. A. 1983. Photoadaptation and diel periodicity of photosynthesis in the dinoflagellate Prorocentrum mariae-lebouriae. Mar. Ecol.-Prog. Ser., 13:73-85.

JEFFREY, S. W. \& HUMPHREY, G. F. 1975. New spectrophotometric equations for determining chl-a, b, $c_{1}$ and $c_{2}$ in higher plants, algae and natural phytoplankton. Biochem. Physiol. Pfl., 167:191-194.

\& VESK, M. 1977. Effect of blue-green light on photosynthetic pigments and chloroplast structure in the marine diatom Stephanopyxis turris. J. Phycol., 13:271-279.

1980. Algal pigment systems. In: Falkowski, P. G., ed. Primary productivity in the sea. New York, Plenum Press. p. 33-58.

JERLOV, N. G. 1976. Marine optics. Amsterdam, Elsevier. 194 p.

KOHL, J. G. \& NICKLISCH, A. 1981. Chromatic adaptation of the planktonic blue-green alga Oscillatoria redekei van Goor and its ecological significance. Int. Revue ges. Hydrobiol., 66:83-94.

LORENZEN, C. J. 1967. Determination of chlorophyll and phaeo-pigments: spectrophotometric equations. Limnol. Oceanogr., 12:343-346. 
MEESON, B. W. \& FAUST, M. A. 1985. Response of Prorocentrum minimum (Dinophyceae) to different spectral qualities and irradiances: growth and photosynthesis. In: Gray, J. S. \& Christiansen, M. E., eds Marine biology of polar region and effects of stress on marine organisms. London, John Wiley. p. 445-461.

PARSONS, T. R.; MAITA, Y. \& LALLI, C. M. 1984. A manual of chemical and biological methods for seawater analysis. Oxford, Pergamon Press. 173 p.

PERRY, M. J.; TALBOT, M. C. \& ALBERTE, R. S. 1981. Photoadaptation in marine phytoplankton: response of the photosynthetic unit. Mar. Biol, 62:91-101.

PRÉZELIN, B. B. 1976. The role of peridinchlorophyll a-proteins in the photosynthetic light adaptation of marine dinoflagellate Glenodinium sp. Planta, 130:225-233.

1981. Light reactions in photosynthesis. In: Platt, T., ed. Physiological bases of phytoplankton ecology. Can. Bull. Fish. aquat. Sci., (210):1-43.

; GLOVER, H. E.; VER HOVEN, B.; STEINBERG, D.; MATLICK, H. A.; SCHOFIELD, O.; NELSON, N.; WYMAN, M. \& CAMPBELL, L. 1989. Blue-green light effects on light limited rates of photosynthesis: relationship to pigmentation and productivity estimates for Synechococcus populations from the Sargasso Sea. Mar. Ecol.-Prog. Ser., 54:121-136.
RICHARDSON, K.; BEARDALL, J. \& RAVEN, J. A. 1983. Adaptation of unicellular algae to irradiance: an analysis of strategies. New Phytol., 92:157-191.

SHIMURA, S. \& FUJTA, Y. 1975. Changes in the activity of fucoxanthin-excited photosynthesis in marine diatom Phaeodactylum tricomutum grown under different culture conditions. Mar. Biol., 33:185-184.

VESK, M. \& JEFFREY, S. W. 1977. The effect of blue-green light on photosynthetic pigments and chloroplast structure in unicellular marine algae from six classes. J. Phycol., 13:280-288.

WALLEN, D. G. \& GEEN, G. H. 1971a. Light quality in relation to growth, photosynthetic rates and carbon metabolism in two species of marine plankton algae. Mar. Biol., 10:34-43.

\& 1971b. Light quality and concentration of proteins, RNA, DNA and photosynthetic pigments in two species of marine plankton algae. Mar. Biol., 10:44-51.

ZAR, J. H. 1984. Biostatistical analysis. Englewood Cliffs, Prentice Hall. p.718.

(Manuscript received 20 January 1991; revised 5 November 1991; accepted 7 November 1991) 